\title{
Wyrok Sądu Metropolitalnego w Katowicach (c. Sobański) z 12.3.1999 r. z tytułu podstępnego wprowadzenia w błąd : "małżeństwo muzułmanina"
}

Ius Matrimoniale 5 (11), 241-250

2000

Artykuł został zdigitalizowany i opracowany do udostępnienia w internecie przez Muzeum Historii Polski w ramach prac podejmowanych na rzecz zapewnienia otwartego, powszechnego i trwałego dostępu do polskiego dorobku naukowego i kulturalnego. Artykuł jest umieszczony w kolekcji cyfrowej bazhum.muzhp.pl, gromadzącej zawartość polskich czasopism humanistycznych i społecznych.

Tekst jest udostępniony do wykorzystania w ramach dozwolonego użytku. 
Ius Matrimoniale

5 (11) 2000

\section{Wyrok Sądu Metropolitalnego w Katowicach (c. Sobański) $z$ 12.3.1999 r. $z$ tytuhu podstępnego wprowadzenia $w$ błąd („małżeństwo muzułmanina").}

\section{PRZEBIEG SPRAWY:}

HM wyznania muzułmańskiego, oraz JZ, wyznania rzymsko-katolickiego, zawarli małżeństwo 27. 12. $1990 \mathrm{w}$ kościele parafialnym w W. Dnia 4. 6. 1997 JZ złożyła w Sądzie Metropolitalnym w Katowicach skargę o orzeczenie nieważności małżeństwa, którą uzasadniła przekonaniem, ,że mąż wyłudził ode mnie zgodę na zawarcie małżeństwa składając obietnice, których nie zamierzal dotrzymać". Sprawę przyjęto do procesu 27. 6. 1997. Jego przedmiot ustalono w formie pytania, czy udowodniono nieważność małżeństwa stron $z$ tytułu podstępnego wprowadzenia w błąd powódki przez pozwanego. Na prośbę powódki, uzasadnionej jej wyjazdem zagranicę, przeprowadzenie instrukcji zarządzono dopiero 21.1.1998. Po jej przeprowadzeniu Sąd orzekł jak następuje.

\section{MOTYWY PRAWNE:}

Zgodnie $\mathrm{z}$ tenorem skargi jako prawną podstawę sprawy przyjęto k. 1098: „Kto zawiera malzeństwo, zwiedziony podstepem, dokonanym dla uzyskania zgody malżeńskiej, a dotyczacym jakiegoś przymiotu drugiej strony, który ze swej natury może poważnie zaklócić wspólnotę życia matżeńskiego, zawiera je niewaznie". Norma ta zostanie poddana interpretacji poniżej, w trakcie przyporządkowania do niej stanu faktycznego.

Sąd uważa za właściwe zwrócić uwagę, że w rozpatrywanej sprawie mamy do czynienia $z$ kompleksem problemów ujmowanych w literaturze kanonistycznej pod nazwą ,,małżeństwo muzułmanina” (S.Villegiante, Matrimonio cattolico e matrimonio musulmano: due mondi a confronto 
nel matrimonio dispari, Mon. Eccl. 1986, 463-509). Islam to nie tylko religia, ale wyraz pewnej kultury zakorzenionej $w$ wierze w Boga. Wiara muzułmanina nie jest czymś wewnętrznym, lecz przenika jego życie rodzinne i społeczne: wiara i kultura pokrywają się. Gdy chodzi o muzułmańską koncepcję małżeństwa, trzeba zwrócić uwagę m.in. na l) hierarchiczne podporządkowanie żony mężowi, 2) obowiązek żony posłuszeństwa mężowi i obowiązek męża sprawiedliwego traktowania żony, 3) przysługiwanie władzy rodzicielskiej wyłącznie mężowi, 4) wykluczenie (ugruntowane w tradycji islamskiej, a w niektórych krajach sankcjonowane ustawowo) możliwości wychowania potomstwa w religii odmiennej niż ojcowska, 5) regulacje dotyczące rozwodu (przy tym podkreśla się $\mathrm{w}$ literaturze, że muzułmanin $\mathrm{z}$ reguły dochowuje wierności żonie) (S.Villegiante, a.c. 509). Małżeństwo muzułmanina $z$ katoliczką może zostać zaskarżone o nieważność jak każde inne małżeństwo, zgodnie $z$ przepisami prawa kanonicznego. Ponadto mają mieć do niego zastosowanie normy dotyczące rozwiązania małżeństwa na podstawie przywileju wiary (A. Abate, Lo scioglimento del vincolo coniugale, wyd. 2,1965).

\section{STAN FAKTYCZNY}

1. $Z$ dokumentów zawartych w aktach sprawy wynika:

a) HM podał przy protokole przedślubnym, że jest mahometaninem. Proboszcz parafii w Cz. zwrócił się 14. 12. 1990 do Kurii Diecezjalnej o dyspensę od przeszkody różnej religii. Dyspensy udzielono 17.12.1990 (VE 46581/90).

b) HM złożył oświadczenia wymagane k. $1086 \S 2$.

c) Ambasada Tunezji w Warszawie poświadczyła, że „według wyciągu $\mathrm{z}$ rejestru stanu cywilnego nr 20, wydanego w R. dnia 03/10/ 1990 Pan HM jest kawalerem".

2. Skargę o orzeczenie nieważności małżeństwa powódka uzasadnia przekonaniem, że pozwany, „wyłudził zgodę na zawarcie małżeństwa składając obietnice, których nie zamierzał dotrzymać". W tejże skardze pisze: „, Maż przyrzekt mi, że: l) Nie będzie utrudniat ukończenia moich studiów; 2) Zapewni mi pelnq swobode praktyk religijnych oraz prawo do katolickiego wychowania dzieci i spetni wszystkie warunki wymagane do zawarcia matżenstwa kościelnego;

3) Nie będzie nigdy zmuszat mnie do zamieszkania na state poza Pol$s k q "$. Zeznając powódka twierdzi, że obietnice, których nie zamierzał 
dotrzymać, pozwany złożył świadomic: „Pozwany zrobil to świadomie, tzn. już w momencie skladania tych przyrzeczen wiedzial, że ich nie dotrzyma, a nawet nie może ich sktadać, ale tez wiedzial, że gdyby tych przyrzeczen nie zlożyt, to ja bym się nie zgodziła na ślub-stad pozwany wyludzil moja zgodę na ślub poprzez swoje fikcyjne przyrzeczenia. Sam mi sie potem pozwany do tego przyznat - wziat cała winę na siebie i powiedzial, iż uczynit tak dlatego, że bardzo chciat tego ślubu ze mnq. Matzeństwo nasze rozpadto sie, gdy wyszto na jaw, ze pozwany swych obietnic nie chce dotrzymać - zaczat mi zabraniać brać dziecko do kościola, twierdzil, że dziecko jest muzulmaninem po ojcu itd. Wiele jeszcze prowadzilam rozmów z pozwanym, aby ratować to nasze malżeństwo, ale nie daly one rezultatu. Przed ślubem wierzylam obietnicom pozwanego - on chodzit ze mna do kościola, swojej religii nie praktykowat, stad uważatam, ze obietnice pozwanego sq szczere. Muszę przyznać, że mnie ostrzegano przed tym matżeństwem, znalam w zarysie zatożenia islamu, ale uważałam, że nie można tego generalizować, że trzeba na sprawe patrzeć jednostkowo, indywidualnie, a w tym wypadku pozwanego nie widziałam u niego jakichś objawów ślepego fundamentalizmu - nie wzbraniat sie przed przekroczeniem progu kościota, wydawat sie otwarty na inne poglady, szczery w swych rozmowach ze mna o naszej przyszłości". Zaufanie, jakim darzyła pozwanego, powódka tak opisuje: „Poznaliśmy się w Londynie - bytam tam na kursie języka i razem z pozwanym pracowatam. Zaprzyjaźniliśmy sie - dość szybko zaczęliśmy mówić o malżeństwie. Ja wiedziatam, że muszę wracać na studia i dlatego od razu jasno stawialam sprawe, że nie odstapie od mojej religii i dzieci będe wychowywata po katolicku, i że gdyby miat być ślub to tylko w kościele katolickim - nie chcialam wyjeżdzać z Londynu i rozstawać się z pozwanym w jakimś rozdwojeniu. Pozwany na wszystko się zgadzat-nie widziałam, aby odprawial modty swojej religii, raczej rozmawialiśmy o tym, iz tak oni-muzutmanie, jak $i$ my - katolicy wierzymy $w$ tego samego Boga i to nas nie powinno dzielić. Pozwany musiat zdawać sobie sprawe z tego, że ja jestem bardzo przywiazana do swej religii, bo w Londynie co niedziela chodziłam do polskiego kościoła na msze s'w. pozwany potem chodzil tam ze mna. Do Londynu przyjechalam w marcu 1990, pozwanego poznalam w maju, a wyjeżdzatam we wrześniu już $z$ gotowymi planami, że sie pobierzemy - najpierw byly plany, że ślub cywilny będzie w Tunezji, a kościelny w Polsce, ale potem tak wyszlo, że oba śluby byty w Polsce. Musze powiedzieć, że zrodzilo się we mnie uczucie do pozwanego, czułam także jego wzajemność - okazywalismy sobie 
tę milość, wspótżyliśmy także cieleśnie ze sobq". W trakcie przygotowań przedślubnych pozwany potwierdzał swe przyrzeczenia w rozmowie $\mathrm{z}$ ks. DS. Przed ślubem zaistniał taki incydent; , $W$ zachowaniu pozwanego nie bylo zmiany po jego przyjeździe do Polski-dalej okazywat mi milość i chcial ślubu ze mnq. Pamiętam jednak, że już przed ślubem pozwany rzucit takie pytanie, co bym powiedziata, gdyby nasze dzieci nie byly ochrzczone - bylam zaskoczona tym pytaniem po tych wszystkich rozmowach, które odbylismy, lzy stanety mi w oczach i zapytatam go, czy on rzeczywiście chce, aby nasze dzieci nie byly ochrzczone pozwany wtedy sie zawahat $i$ wycofat sie, powiedzial, że dzieci moga być ochrzczone. Gdyby mi wtedy pozwany powiedzial, że nie chce, aby dzieci byly ochrzczone, to na pewno bym jeszcze wtedy ślub odwotata. Szłam do ślubu w przekonaniu, ze obietnice pozwanego sq szczere i że on tych przyrzeczeń dotrzyma-pozwany potwierdzil i podpisat te przyrzeczenia przy protokole przedślubnym, także $w$ rozmowach z mojq mamq potwierdzal te swoje obietnice. Tak więc szlam do ślubu spokojna-ślubowalam szczerze i chciatam budować matżeńskq wspólnotę z pozwanym". Od dnia ślubu ,wieczorem po weselu pozwany rozwinat dywanik i zaczal odprawiać swe modty - nigdy tego wcześniej nie robit". Konflikt wybuchł po urodzeniu chłopca, pozwany upierał się, że musi mieć imię arabskie, Omar. W trakcie burzliwych rozmów pozwanego $\mathrm{z}$ rodzicami powódki ,,wyszło na jaw, jakie sa prawdziwe plany pozwanego że nie chce dotrzymać obietnic mi danych, że nasz syn będzie muzulmaninem $i$ stad to uparte jego obstawanie przy imieniu Omar - mama wtedy zemdlata $i$ chyba tylko dlatego pozwany zgodzil sie na to potaczenie imion Adam Omar". Pozwany zgodzit się na chrzest dziecka, potem raz jeden doszto do ostrej wymiany zdań, ale sprawa przycichla $i$ wybuchta na nowo z okazji roczka dziecka: „Była zamówiona Msza św. i zaproszeni goście na te uroczystość. Temu pozwany się sprzeciwil - kategorycznie stwierdzil, że nie chce, aby dziecko chodziło do kościoła i jeśli ja sie temu nie podporzadkuje, to spowoduje, że wyjedziemy do Tunezji. Ja stwierdzilam wtedy, że jeśli on nie chce, to niech nie idzie do kościołaja $z$ dzieckiem i zaproszonymi gośćmi pójdę. Pozwany jednak się złamal i gdy przyjechali goście, poszedl z nami wszystkimi do kościoła. W kościele, gdy dziecko zaczęto trochę gtośniej się zachowywać, pozwany je wziat $i$ wyszedl z kościota - zniknal, musiałam go szukać, bo msza się już zaczęła. Zaczęlam się bać pozwanego - szantażowal mnie za to, że został zmuszony do tych kompromisów co do dziecka. Batam się, że może mi zabrać dziecko i wyjechać do Tunezji-dowiadywatam się o to 
$i$ stwierdziłam, że jest taka możliwość. Przy tych rozmowach z pozwanym w tym czasie staratam sie go zrozumieć i wtedy on mi powiedziat, ze jako muzutmanin nie miat prawa dawać mi takich obietnic, jaki mi złożyt, $\dot{z} e$ z góry wiedzial, iz ich nie dotrzyma - on stawiat to tak, $\dot{z} e$ zloży takie fikcyjne przyrzeczenia, aby ślub mógt sie odbyć. Pozwany widziat, że ja postepuje $w$ dobrej wierze $i$ stad postanowil wziać te wine na siebie, a ja powinnam się z tym pogodzić. Wedlug pozwanego wich tradycji, to ojciec przekazuje wiarę $i$ on decyduje o przynależności religijnej dziecka. Syn muzutmanina zawsze będzie muzutmaninem i z tego pozwany zrezygnować nie może - stqd nasz syn nie może chodzić do kościoła. Jeśli natomiast ja bralabym syna do kościola, to pozwany może stać się niebezpieczny, bo on sobie na to nie może pozwolić sam mi to pozwany wyjaśnial i stad rzeczywiście zaczętam sie go bać. Szantaże powtarzaly się we wszystkie uroczystości religijne - we Wszystkich Świętych, na Mikotaja, Boże Narodzenie, w czasie kolędy - pozwany twierdzil, że nasz syn nie może w tym brać udzialu, straszył ciagle wyjazdem do Tunezji-wiedziałam, że pozwany mógłby dostać paszport na dziecko i wyjechać $z$ nim, batam się coraz bardziej". Powódka czuje się „oszukana tym małżeństwem”, uważa, że jej zgoda została wyłudzona, bo pozwany wiedział, że gdyby nie złożył przyrzeczeń, małżeństwo nie doszłoby do skutku.

3. Pozwany nie zjawił się w Sądzie, nie zareagował na pisma Sądu. $Z$ przeprowadzonego wywiadu wynika, że rzeczywiście mieszka pod podanym adresem i ,według opinii sąsiadów jest muzułmaninem".

4. Ks. DS miał styczność z pozwanym dwa razy: przy spisywaniu protokołu na prośbę proboszcza $z \mathrm{~W}$. oraz przy ceremonii ślubnej, świadek nie pamięta, czy spotkał się z pozwanym przy umawianiu się na protokół. Świadek pamięta, że ,pozwanego nie trzeba było specjalnie namawiać do podpisania tych wymaganych klauzul, pozwany podpisat je bez problemów”, a ceremonia ślubna ,przebiegała bez zakłóceń”.

5. Zeznawali rodzice i wujek powódki.

Matka powódki zeznaje: ,Pozwany wedlug mnie jest osobq zupetnie niewiarygodnq - takim się okazat, bo na poczqtku wierzyliśmy w jego deklaracje, ale potem okazato się, że pozwany zmienia poglady, mówi $w$ danej chwili to, co mu odpowiada, aby osiagnać jakiś swój cel. Ja najbardziej przeżylam rozpad tego matzeństwa stron, bo pozwany oszukat mnie dwukrotnie - przed ślubem, ponieważ córka bezgranicznie ufata pozwanemu, staraliśmy się mu z moim mężem także zaufać, pozwany wydawat się być wiarygodny. Pozwany zobowiqzywat się wtedy, że nie 
będzie przeszkadzat córce w ukończeniu studiów, że nie będzie wymagal od córki opuszczenia ojczyzny, a w kwestii religijnej zobowiazat sie, że nie będzie córce przeszkadzal w wyznawaniu wiary katolickiej, że dziecko będzie wychowane $w$ wierze katolickiej, że podporzqdkuje się wszystkiemu, czego wymaga protokót przedmatżeński - byly dlugie rozmowy ukazujace pozwanemu charakter sakramentalny matżenstwa $w$ tym naszym ujęciu, że takie matżenstwo jest nierozerwalne, monogamiczne itd. Nas rodziców niepokoilo takie matzeństwo i staraliśmy się zabezpieczyć przyszłość tego matżeństwa, więcej zrobić nie szto. Nawet ks. DS. przeprowadzajacy rozmowy z pozwanym byt przekonany o jego dobrej woli podporzadkowania się wszystkim wymaganiom kościelnym, wszystkiemu czego oczekiwata córka i my, jeśli chodzi o to matżeństwo. Nie można powiedzieć, że pozwany nie wiedziat, czego się od niego wymaga, zeby byt nieświadomy do czego się zobowiqzuje - mogę dostarczyć kopię listu przedślubnego, w którym pozwany deklaruje petnq tolerancję, zwlaszcza religijna. Wedtug mnie pozwany dziatat podstepnie - córka bez tych zapewnień i zobowiazań pozwanego na pewno by tego matzeństwa nie zawierata i pozwany doskonale o tym wiedzial. Byl świadomy tego, że nie byloby ślubu, gdyby tych przyrzeczeń córce nie ztożyt-wedtug mnie jednak od poczatku pozwany zdawat sobie sprawe, że tych zobowiqzań nie dotrzyma. Pozwany wytudzit więc podstepnie zgodę córki na ten ślub. Zreszta potem sam pozwany się do tego przyznat, iż tylko dlatego złożyt te przyrzeczenia, aby mogto dojść do tego kontraktu. Pierwsze odstonięcie prawdy miało miejsce 3 dni po urodzeniu się dzieckao tym wiedziałam tylko ja. Styszałam jak przez telefon pozwany gtośno i ostro rozmawial z córka i córka mnie zobowiqzała, abym przeprowadzila z pozwanym rozmowe o wyborze imienia dla dziecka. Chodzito o kompromis - córka nie chciala wybierać imienia bardzo chrześcijańskiego, ale takie uniwersalne, które jest uznawane we wszystkich religiach monoteistycznych. Pozwany jednak temu ostro sie sprzeciwil wtedy po raz pierwszy powiedzial, że syn muzulmanina jest muzutmaninem i tu nie ma o czym dyskutować. Byłam zdruzgotana oświadczeniem pozwanego, który stwierdzil, iz te wszystkie przyrzeczenia $i$ zobowiazania nie sa dla niego wazne, nie dotycza go, bo on nawet nie miat prawa takich przyrzeczeń zlożyć. Bytam zszokowana i zorientowałam sie, jaka gehenna czeka mojq córkę - zemdlatam i pozwany widzac takq mojq reakcje zareagowat po ludzku i aby mnie uspokoić powiedziat, że tej naszej rozmowy nie byto, ze on jednak te wszystkie zobowiqzania wypetni itd. Nikomu o tej rozmowie nie powiedzieliśmy - pozwany poszedl na 
kompromis i dziecko otrzymato imię Adam Omar. Ja powtórnie uwierzylam pozwanemu. Powtórnie sprawa wybuchta przy roczku dziecka - wtedy pozwany zabronit z dzieckiem iść do kościota i powiedzial córce to wszystko, co mnie powiedzial przy urodzeniu się dziecka - córka przyleciata do mnie z placzem $i$ wszystko mi opowiedziala. Zadecydowaliśmy, że roczek i tak się odbędzie, a pozwany jak nie chce to nie musi iść do kościota - myśmy jako rodzice przyjęli stanowisko neutralne, nie chcieliśmy się wtrącać, nawet mojemu mężowi jeszcze nic nie mówiliśmy. Resztę strony uzgadniaty między sobq - z pozwanym już nie prowadziliśmy pertraktacji. Ze strony pozwanego pojawily sie zagrożenia, że wywiezie dziecko do Tunezji i córka byla zmuszona odejść od pozwanego, aby on nie wiedzial, gdzie jest dziecko. Córka opuścila pozwanego w obliczu zagrożenia uprowadzenia dziecka - to byto w styczniu 1993. Wtedy dopiero o calej sprawie dowiedzialy się inne osoby. Na życzenie pozwanego odbyto się jeszcze kilka rozmów ze mnq i moim mężem. Wtedy mi pozwany wyttumaczyt tę swoja filozofię życiowa-powiedzial wyraźnie, ze tylko dlatego podpisal te wszystkie zobowiqzania, bo gdyby tego nie zrobil, to on zdawal sobie sprawe, że do kontraktu by nie doszlo. I mial racje, myślat dobrze, bo tak by rzeczywiście bylo. Pozwany twierdzil, że gdyby jego rodzina wiedziata, że coś takiego zrobil, to by go zabili-ja myślę, że ta jego rodzina w Tunezji do dziś nie wie, do czego pozwany się zobowiazat. Pozwany twierdzil, że może sie jeszcze zgodzić na ateistyczne wychowanie dziecka, ale absolutnie nie na katolickie. Pozwany twierdzil, że bierze winę na siebie - córka jest niewinna, bo ona musi stuchać męża".

Podobne w treści są zeznania ojca powódki.

Świadek AK. relacjonuje rozmowę z pozwanym, w której ten twierdził, że nie zmieni religii, a syn musi być wychowany jako muzułmanin. Pozwany usiłował thumaczyć świadkowi, że ,nie wiedział, do czego się zobowiązal", nie powiedział, że podpisał zobowiązania z obawy, iż nie będzie ślubu - świadek nie wierzy pozwanemu.

6. Powódka wniosła 30.1.1993 do Sądu Rejonowego w R. o powierzenie jej władzy rodzicielskiej nad synem Adamem. Wniosek uzasadniła następująco: ,, Od chwili urodzenia dziecka w matżeństwie naszym wystapily poważne konflikty powstate w wyniku niedotrzymania przez uczestni$k a$ postępowania zobowiazań warunkujacych zawarcie malzeństwa. $Z$ wypowiedzi uczestnika wynika, że podjętych zobowiazań z góry nie zamierzat dotrzymać, określajac je jako nie majace dla niego znaczenia. Uczestnicy uzgodnili m.in., że maż nigdy nie będzie zmuszal żony do za- 
mieszkania w innym kraju. Od maja 1992 , maż stanowczo odmawia realizacji zobowiqzań wynikajacych z zawarcia ślubu katolickiego i odgraza się zastosowaniem przymusu wyjazdu do Tunezji". Brak w aktach decyzji Sądu Rejonowego, natomiast Sąd Wojewódzki w K. orzekając 7. 3. 1997 rozwód małżeństwa stron powierzył powódce wykonywanie władzy rodzicielskiej nad małoletnim Adamem Omarem, zastrzegając pozwane$\mathrm{mu}$,prawo współdecydowania o istotnych sprawach dziecka”, utrzymywania $\mathrm{z}$ nim kontaktów osobistych i widywania się z nim „w miejscu zamieszkania dziecka”, ale „bez prawa zabierania ze soba”.

7. Wobec watpliwości, jakie może nasuwać ,małżeństwo muzułmanina", trzeba ustalić fakty bezsporne i na ich tle wyakcentować pytanie procesowe.

a) Nie ulega wątpliwości, że została zachowana forma zawarcia małżeństwa. Powódka zawarła je w obowiązującej ją formie kanonicznej, pozwany jako obywatel tunezyjski przebywający poza granicami Tunezji miał prawo zawierać je w formie obowiązującej w miejscu jego zawarcia. Nie wiadomo, czy - zgodnie z prawem tunezyjskim - zgłosił w konsulacie fakt zawarcia małżeństwa, ale wymóg ten nie jest wymagany do ważności związku (J. Prader, Il matrimonio nel mondo, wyd. 2, 1986,585).

b) Nie istnieją podstawy do zakwestionowania ważności udzielonej dyspensy od przeszkody różnej religii. W prośbie o dyspensę podano przyczyny skłaniające do jej udzielania, spełniono też warunki określone k. 1125 i 1126. Dla ważności dyspensy nie ma znaczenia, czy istniała rzeczywiście wola ich spełnienia (J. Prader w AfkKR 1993, 99).

c) Nie ma podstaw do zakwestionowania woli małżeńskiej pozwanego. Ustawą z 13.8.1956 (obowiązującą od 1.1.1957) zniesiono w Tunezji poligamię (J. Prader, Il matrimonio..., 583), co każe domniemywać, iż pozwany przyswoił sobie definicję monogamicznego małżeństwa.

d) Pozostaje przeto do rozpatrzenia - i taki jest przedmiot sprawy kwestia, czy pozwany zawierając małżeństwo wprowadził powódkę w błąd i to (1) co do przymiotu mogącego ze swej natury zakłócić wspólnotę życia małżeńskiego oraz (2) w obawie, że w przeciwnym razie ona nie zawsze $z$ nim małżeństwa, które on pragnął.

8. Rozpatrywanie sprawy napotyka dużą trudność z powodu braku zeznań - i jakiegokolwiek wyjaśnienia - ze strony pozwanego. Wobec jego bezproblemowego złożenia podpisów pod protokołem przedślubnym i przyjętą w Polsce formułą oświadczeń wymaganych k. 1125 trzeba dać wiarę 
zeznaniom powódki i świadków twierdzących, iż pozwany zgadzał się nie tylko na kanoniczną formę małżeństwa, lecz także na katolicką przyszłość potomstwa. Rodzi się przeto pytanie, czy wprowadził powódkę w błąd po to, by zawrzeć z nią małżeństwo. Trzeba tu najpierw stwierdzić, że zarówno faktycznie jak i prawnie pozwany mógł zawrzeć małżeństwo tylko w formie obowiązującej w Polsce, kanonicznej i (lub) cywilnej. Pewne jest też, że pozwanemu zależało na zawarciu małżeństwa $\mathrm{z}$ powódką. Zaakceptował przeto stawiane mu warunki. Wobec braku wyjaśnień pozwanego, odpowiedź na pytanie, czy uczynił to szczerze czy też wprowadził powódkę w błąd przez zatajenie, musi opierać się na domniemaniu wyprowadzonym $z$ faktów pewnych (k. 1586).

Zgodnie z art. 19 Islamskiej Deklaracji Praw Człowieka z 19.9.1981 muzułmanie mogą zawierać małżeństwo jedynie „w ramach muzułmańskich" (,dans son cadre islamique” - J. Prader w AfkKR 1993, 77). W tych zaś „ramach" władza rodzicielska nad dziećmi przysługuje jedynie ojcu, matka ma tylko obowiązek opieki nad dzieckiem, dopóki ono nie osiagnie wieku określonego ustawa, przy czym matka nie-muzułmanka może wykonywać tę opiekę jedynie w sposób ograniczony, zaś ojciec może pozbawić ją prawa wykonywania tej opieki, jeśli obawia się, że dziecko zostanie wyobcowane z religii muzułmańskiej (J. Prader w AfkKR 1993, 87). Zeznania powódki i świadków dowodzą, iż taka właśnie była postawa pozwanego, potęgowana tym, że chodzi o syna. Te przesłanki każą wyciagnnąć wniosek, że pozwany wprowadził powódkę w błąd i to celem zawarcia małżeństwa.

Pozostaje pytanie, czy można tu mówić o wprowadzeniu w błąd co do przymiotu osoby: wszak pozwany nie taił swojej religii, wprowadzał w błąd jedynie co do swych rzeczywistych zamiarów (nie dotyczących istoty małżeństwa, gdyż wtedy trzeba by rozpatrywać sprawę z tytułu symulacji).

Błąd, o który chodzi w rozpatrywanej sprawie, to taki, który ze swej natury może poważnie zakłócić wspólnotę małżeńską. Znaczy to, że nie może on dotyczyć przymiotu błahego, lecz takiego, który czy to z siebie czy w swych skutkach stanowi potencjalne zagrożenie małżeństwa -wspólnoty zorientowanej na dobro małżonków oraz na wychowanie potomstwa. Chodzi więc o przymiot ,aktywny", determinujący postawy i zachowania, zakotwiczony w formacji duchowej.

Nie ulega wątpliwości, że przymiot oddziaływujący bezpośrednio na sprawy związane $z$ religią potomstwa należy do takich, które ze swej natury moga poważnie zakłócić wspólnotę życia małżeńskiego. Materiał 
dowodowy świadczy, że formacja pozwanego była taka, iż ,syn muzułmanina nie może nie być muzułmaninem". Rzecz więc nie w tym, że pozwany jest muzułmaninem ani w kwestii szczerego złożenia obietnic czy ich dotrzymania, lecz w tym, że pozwany ,nie mial prawa dawać takich obietnic", i że on wedle własnego przekonania jest tym, który decyduje o religii syna. To właśnie, tę „cechę muzułmanina” pozwany zataił, zamaskował ją składanymi obietnicami. Jej faktyczne istnienie ujawniło się w związku z urodzeniem się syna.

Tak więc Sąd Metropolitalny stwierdza, że pozwany zawierając małżeństwo wprowadził powódkę w błąd co do przymiotu swojej osoby, mogącego ze swej natury zakłócić wspólnotę życia małżeńskiego. Na pytanie procesowe Sąd odpowiada przeto twierdząco i stwierdza, iż udowodniono nieważność małżeństwa.

La Sentenza del Tribunale Metropolitano di Katowice (c. Sobañski) del 12.3.1999 dal titolo della deceptio dolosa (,il matrimonio di un musulmano")

\section{Sommario}

La sentenza (pro nullitate) in causa è stata giudicata dal can. 1098 del CUC: il conventuto (un musulmano) ha ingannato l'oratrice circa le promisioni datele riguardo alla religione della prole. 